\title{
Review \\ Carbon Accumulation in Arable Soils: Mechanisms and the Effect of Cultivation Practices and Organic Fertilizers
}

\author{
Jörg Gerke
}

Ausbau 5, 18258 Rukieten, Germany; gerke.rukieten@t-online.de

\begin{abstract}
The organic carbon content of soils is a key parameter of soil fertility. Moreover, carbon accumulation in soils may mitigate the increase in atmospheric $\mathrm{CO}_{2}$ concentration. The principles of carbon accumulation in arable soils are well known. The inclusion of clover/alfalfa/grass within the rotation is a central instrument to increase soil organic carbon. In addition, the regular application of rotted or composted farmyard manure within the rotation can increase soil organic carbon contents much more than the separate application of straw and cattle slurry. Humic substances, as a main stable part of soil organic carbon, play a central role in the accumulation of soil carbon. A major effect of compost application on soil carbon may be the introduction of stable humic substances which may bind and stabilize labile organic carbon compounds such as amino acids, peptides, or sugars. From this point of view, a definite soil carbon saturation index may be misleading. Besides stable composts, commercially available humic substances such as Leonardite may increase soil organic carbon contents by stabilization of labile $\mathrm{C}$ sources in soil.
\end{abstract}

Keywords: humic substances; farmyard manure; alfalfa/clover/grass mixtures; FAO point of view on soil carbon; organic fertilizers

Citation: Gerke, J. Carbon

Accumulation in Arable Soils:

Mechanisms and the Effect of Cultivation Practices and Organic Fertilizers. Agronomy 2021, 11, 1079 https://doi.org/10.3390/

agronomy11061079

Academic Editor: Claudio Ciavatta

Received: 2 May 2021

Accepted: 26 May 2021

Published: 27 May 2021

Publisher's Note: MDPI stays neutral with regard to jurisdictional claims in published maps and institutional affiliations.

Copyright: (C) 2021 by the author. Licensee MDPI, Basel, Switzerland. This article is an open access article distributed under the terms and conditions of the Creative Commons Attribution (CC BY) license (https:// creativecommons.org/licenses/by/ $4.0 /)$.

\section{Introduction}

Soil organic matter has a strong impact on soil fertility [1,2]. Soil organic carbon (SOC) also strongly affects the global $\mathrm{C}$ cycle because it represents the greatest $\mathrm{C}$ pool accounting for $2-5\left(\mathrm{~kg} \mathrm{C} \times 10^{15}\right)[1,3]$. Soils contain more carbon than atmosphere and vegetation combined [4].

At present, the political aim to mitigate or stop the increase of atmospheric $\mathrm{CO}_{2}$ concentration is claimed to be an important goal by many governments. Elevated $\mathrm{CO}_{2}$ levels may be reduced by increased storage of $\mathrm{C}$ in soils as SOC.

The restriction of $\mathrm{CO}_{2}$ emissions by decreased fossil combustion may be an important aspect, but the activation of soils as a carbon sink is of similar relevance.

In this paper, an overview of the principles and mechanisms of soil organic carbon storage and ways to increase this carbon pool in agricultural soils will be given. In a further section, the standpoint view of the FAO, the food and agriculture organization of the United Nations, from 2017, is critically discussed. In the final section, the application of commercially available organic fertilizers will be discussed in their effect to increase soil organic carbon.

\section{Organic Carbon-Some Agronomic Considerations}

The amount of carbon in soils, mainly as SOC, is higher by a factor of 2-8 than that of carbon in the atmosphere. Soils are important carbon sinks and may help to mitigate the elevation of $\mathrm{CO}_{2}$ levels in the atmosphere.

For agricultural soils, Gattinger et al. [5] showed by means of a meta-analysis that the SOC content depends on the method of cultivation. The C contents and the annual C increase were higher in soils which were organically managed compared to conventional management. Gattinger et al. [5] interpreted their results in that way that organic farming 
requires clover/alfalfa/grass as a component in the rotations. This way of cultivation represents a combination of reduced tillage with a high input of organic residues which favors the accumulation of SOC. Gattinger et al. [5] also showed that higher C stocks under organic farming are not the result of a higher external input of organic fertilizers, such as slurry, farmyard manure, or commercial organic fertilizers. In a strict sense, Gattinger et al. [5] presented an explanation for their results but not proof for the effect of alfalfa/clover/grass on soil organic carbon stocks.

The main differences between organic and conventional farming are I. the application of mineral $N$ fertilizers produced by the Haber-Bosch synthesis and II. the application of organic pesticides in conventional farming. As a consequence, the use of clover, alfalfa, and other legumes in organic farming is required to supply the plants with nitrogen from symbiotic fixation within a rotation. In most of the field trials comparing organic and conventional farming, the parameters $N$-fertilization, pesticide application, and clover/alfalfa in the rotation were not treated as independent factors such that the reasons for SOC accumulation remain unclear. A remarkable exception was a field trial conducted from 1982 to 1998 at the Georg-August Universität in Göttingen, where a. alfalfa within the rotation combined with farmyard manure application, $b$. organic pesticide application, and c. N-fertilization at different levels were three independent factors. After 15 years, in 2015, i.e., after 2.5 rotations, the SOC concentrations were about $10 \mathrm{tSOC} /$ ha higher in the treatment with alfalfa in one of the six years of the rotation compared to the rotation without alfalfa [6]. The difference between the rotation with or without alfalfa is only a part of the real difference since only the upper $20 \mathrm{~cm}$ of the soils were considered. Alfalfa contributed only to $16.7 \%$ of the rotation whereas alfalfa/clover/grass mixtures normally account for between 25 and $33 \%$ within the rotation in ecologically managed farming systems. The results from Göttingen show the potential of SOC accumulation by alfalfa/clover/grass as an important part within the rotation.

\section{Mechanisms of Soil Organic Carbon Accumulation in Arable Soils}

In the last decade, several scientific groups have suggested that organic matter introduced to the soil as carbohydrates, lipids, proteins, and lignin are biologically degraded, and this degradation can be impeded by several mechanisms, e.g., binding to the soil solid phase, physical protection, or reduced wettability $[7,8]$. The formation of new soil organic matter (humic substances) from plants and microbial residues in soil is assumed to have no quantitative relevance [7] or is rejected [8]. Within this frame of thinking, an intrinsic stability of soil organic matter is not attributed to soil humic substances but is instead attributed to pyrogenic or black carbon (BC) [7-9].

Schmidt et al. [7] summarized their opinion in the conclusion that there is a soil specific SOC saturation potential which may be overcome by adding recalcitrant BC in form of biochar.

It has been published in several papers that high $\mathrm{BC}$ concentrations were found in highly fertile soils, Chernozems [10,11], fertile Australian soils [12], fertile Amazonian terra preta soils [13], and fertile US soils [14,15]. The authors found between 30 and $45 \%$ $\mathrm{BC}$ within SOC and concluded that soil fertility in arable soils was associated with huge amounts of BC. Several of the authors of these papers also contributed to Schmidt et al. [7]. However, in the paper of Schmidt et al. [7], they did not mention their own results on BC in arable soils. Instead, they reported of up to $40 \%$ BC of SOC in grassland and boreal forests. The reason for ignoring the own results is obvious. The methods for $\mathrm{BC}$ determination which were adopted in their papers strongly overestimate soil BC [16-19]. However, $\mathrm{BC}$ determination in forest and grassland soils is mostly conducted by the use of the same methods as used for arable soils which, in general, make the conclusions on BC by Schmidt et al. [7] questionable.

The confusion on BC determination in soils is strongly connected with humic substances in soil. 
The group around K. Schmidt-Rohr published a paper in 2012 [15] where they found, by means of ${ }^{13} \mathrm{C}$ NMR spectroscopy, aromatic carbon with fused aromatic rings and $\mathrm{COO}^{-}$groups in mollisols and terra preta soils. Based on the previous results by Schmidt et al. [10,11], Skjemstad et al. [12,14], and Glaser et al. [13], they fully attributed the aromatic carbon to the existence of $\mathrm{BC}$ or char which was then interpreted to account for $40-50 \%$ of SOC.

However, the times are changing, and in 2018 members of the group of SchmidtRohr published a paper in which the existence of abundant non-protonated aromatic and oxygen-bonded carbon was interpreted as a distinct and unique feature of humic substances differing from biopolymers from plant or microbial origin [20].

In the meantime, results from DiDonato et al. [21] and Waggoner and Hatcher [22] showed that polycyclic aromatic carbon (PAC) species can be formed from lignin, e.g., by adding Fenton reagent (Fe(II) salt $+\mathrm{H}_{2} \mathrm{O}_{2}$ ), which shows that PAC in soil may be formed during the degradation of lignin. These results destroy the theory on organic carbon degradation by Lehmann and Kleber [8] and Schmidt et al. [7] which rejects the de novo formation of soil organic substances. Piccolo [23] argued that the suggestions by Schmidt et al. [7] should have been supported by the formulation of chemical pathways of soil organic carbon transformation.

It should be noted that Ziechmann [24] already described the formation of PAC structures in humic substances after the reaction of lignin with Fenton reagent.

The conclusions from these results are:

1. Most of the $B C$ in soils determined by the most common $B C$ determination methods may actually determine PAC structures in humic substances [18,19].

2. Reaction pathways can be described by which PAC structures in humic substances are formed $[21,22,24]$.

3. PAC structures are unique components of soil humic substances $[20,25,26]$.

Marschner et al. [9] found that only BC (besides fossil C) showed some recalcitrance in soils. However, Marschner et al. [9] determined BC in soils by the benzene polycarboxylic acid method after Brodowski et al. [27], which mostly determines PAC in humic substances and not BC [18]. Considering this misinterpretation, Marschner et al. [9] unintentionally supported, to some extent, the view of recalcitrant humic substances.

Soil organic carbon recalcitrance may strongly contribute to higher levels of SOC in soil. Boudot [28] showed that for citrate, this organic molecule is easily degraded by microbes if it exists in free form in the soil solution. However, if citrate is complexed by $\mathrm{Al}$ or adsorbed to $\mathrm{Al}$ surfaces such as $\mathrm{Al}(\mathrm{OH})_{3}$ or imogolite, its mineralization is strongly reduced. Similar results were reported by Jones and Edwards [29] for carboxylates adsorbed to Fe surfaces. Boudot [28] also showed by calculation that complexation or adsorption of easily degradable molecules such as citrate alone do not explain SOC contents in soils. Additionally, recalcitrance of soil organic carbon against degradation is required to explain carbon levels in soils.

Humic substances with its intrinsic stability against degradation may strongly contribute to SOC accumulation in soils $[30,31]$. They may initially be formed from aromatic monomers from lignin degradation or from microbial origin [30,32].

The then newly formed aromatic core may bind lipids, proteins peptides, lignin, carbohydrates, and other polar or non polar molecules [33].

The way in which soil humic molecules are formed is still a matter of debate. They may be true macromolecules [34] or supramolecular associations of relatively small molecules as introduced by Piccolo and coworkers [35-37], or a combination of both [38].

A certain mediation between the macromolecule view and that of supramolecular associations is achieved by the results of Piccolo and coworkers [39-41] who showed that supramolecular humic associations can polymerize to true macromolecules by adding phenolases or by UV irradiation of humic substances. This may lead to the conclusion that in soil, often or sometimes, the concentration of substrate (aromatic monomers) or catalyst (e.g., oxidoreductases) is so low that polymerization of humic substances is restricted and 
that both supramolecular humic associations and humic macromolecules may contribute to the system of soil humic substances. The supramolecular association of humic molecules may also explain the high plasticity of humic substances reacting to changes of chemical conditions [23]. The question, however, still remains unresolved: of which chemical forces are responsible for the formation of supramolecular associations.

Humic substances may contribute up to $50-80 \%$ of SOC $[2,36]$. Stable humic substances can incorporate organic molecules and stabilize them. Martin, Haider, and coworkers showed this stabilization for amino acids and peptides. In free form, amino acids and peptides are easily degraded in soil within 1-3 months [42]. If amino acids or peptides are incorporated into humic acids from different origin, the rate of microbial decomposition is strongly reduced to between 6 and 24\% within one year, depending on different soils and $\mathrm{N}$ forms [43]. Martin and Haider [44] gave an overview for these reactions.

Piccolo et al. [45] showed a similar stabilization in soil for carbohydrates after adding stable compost humic substances.

Both peptides and carbohydrates are easily degradable by soil organisms in free form. The binding to and the incorporation into humic molecules or into the humic framework strongly reduces the microbial degradation.

\section{Compost and Farmyard Manure Application}

The application of farmyard manure to soil can strongly increase soil organic carbon contents much more than the separate application of the components straw and cattle slurry [46]. The main reason may be the formation of stable organic matter, mainly humic substances, during the ripening or composting of the manure. Composting farmyard manure or other organic substrates seems to be a very effective method to supply soils with stable organic carbon species. The relation between compost ripening and the formation of humic substances (humification) has been described [38,47-55]. Compost ripening is connected with humification and, often, the aromaticity of the compost humic substances is increased during humification [38,49-51,53] and the content of PAC is also increased [50]. Ikeya et al. $[25,26]$ suggested that PAC structures in humic substances are a main factor of intrinsic recalcitrance. The intensity and extent of transformation and synthesis during compost formation is documented by Smidt et al. [54], who found the incorporation of high quantities of lignin into the formed humic substances during composting. Weichelt [56] showed the incorporation of lignin into model humic substances from pyrogallol during humification.

Piccolo et al. [31] argued that the application of stable humic substances, e.g., in form of composts, creates new binding sites for organic carbon. This is in direct contrast to the concept of $C$ saturation of soils according to Schmidt et al. [7], which excludes humification as a relevant process for soil organic matter formation.

The interaction of compost application and the cultivation of clover/alfalfa/grass components within an agronomic rotation and its effect on SOC are out of any scientific discussion. What happens if stable humic substances are added to soil which is cultivated with crops such as alfalfa, which combine long time growth without soil tillage with a high release of organic materials such as root exudates, dying roots, leaves, and stalks? The degradation products may be bound to and stabilized by humic substances. A high concentration of phenolic compounds may accumulate at the humic surface which may give support to a (further) polymerization of humic compounds. In general, the polymerization of humic compounds may be limited because of the limitation of substrate (phenolic monomers) and/or by a reduced activity of catalysts such as phenolases, clay minerals, or Fe/Mn oxides [30]. One aspect of the supramolecular association of humic substances, as developed by Piccolo and coworkers, is that the relatively small humic units forming the associations may react to higher molecular weight molecules if catalysts such as phenolases [39,40] or Mn catalysts combined with UV irradiation [41] are applied. 
A higher substrate concentration, e.g., during the cultivation of alfalfa/clover/grass, may compensate for a reduced activity of catalyst and may support polymerization of humic substances.

What are the intermolecular forces which hold together and stabilize the humic subunits? Humic substances may be considered as a system [24] or as supramolecular association [35-37,41]. Piccolo and coworkers emphasize the role of hydrophobic interactions/dispersive forcesand hydrogen bonds. Ziechmann [24] emphasizes van der Waals forces, hydrogen bonds, and electron donor-acceptor complexes which may stabilize the aggregation of humic substances withina humic system.

The aggregation of humic subunits is probably strongly affected by the bridging by metals such as $\mathrm{Fe}(\mathrm{III}), \mathrm{Al}(\mathrm{III})$, perhaps $\mathrm{Cu}(\mathrm{II})$, and possibly $\mathrm{Ca}(\mathrm{II})$.

Strong complexants such as di- and tricarboxylic acids can break metal bridges and increase the solubility of soil humic substances by reducing the apparent molecular masses and by increasing the hydrophilicity of the humicmolecules. These reactions are important in rhizosphere chemical processes, where plant roots can excrete carboxylic acids at high rates which dissolves humic molecules by breaking the metal bridges [57-62].

In Figure 1a, the principal action of citrate on breaking Al bridges which link humic subunits is shown. The hydrophilizing effect on humic matter by the introduction of ternary humic-Al-citrate complexes is described in Figure 1b. Both the removal of bridging $\mathrm{Al}$ ions and the formation of ternary complexes, e.g., by respectively with citrate may explain the reduction of apparent molecular size of humic molecules and the increase of humic solubility in soil as a result of carboxylate release, e.g., by plant roots.

a.

$$
H S_{1}-A l-H S_{2}+C i t r{ }^{\ominus} \rightleftarrows H S_{1}+A l-C i t r+H S_{2}^{\ominus}
$$

b.

$$
H S_{1}-A l-H S_{2}+C i t r{ }^{\ominus} \rightleftarrows H S_{1}-A l-C i t r+H S_{2}^{\ominus}
$$

Figure 1. Principal mode of action of citrate on breaking $\mathrm{Al}$ bridges of humic subunits, $\mathrm{HS}_{1}, \mathrm{HS}_{2}$ (a) and the formation of a ternary humic-Al-citrate complex (b).

\section{Reaction of Soil Organic Carbon with Inorganic Soil Components}

The stability of soil organic carbon against microbial degradation may be affected by the reaction of organic matter with inorganic surfaces such as oxides, clay minerals, aluminosilicates, and silicates [63]. Complexation by metals such as $\mathrm{Al}(\mathrm{III})$ and $\mathrm{Fe}(\mathrm{III})$ and surface complexation of organic matter mainly of carboxylic and phenolic groups [64] may be relevant for SOC stability $[28,29,65]$.

In this line of explanation of SOC preservation by inorganic soil components, Ellerbrock and Gerke [66] related SOC accumulationto the quantity of polyvalent cations, Ca, $\mathrm{Mg}, \mathrm{Al}, \mathrm{Fe}$, and $\mathrm{Mn}$ in soil by considering three types of interaction, organic matter-cation, organic matter-cation-mineral surface, and organic matter-mineral surface. The corresponding metal fractions were defined as exchangeable cation, oxalate extractable cation, and dithionite extractable cation, respectively. They related the ratio of $\mathrm{C}=\mathrm{O}$ groups (carboxylic and carbonylic) versus $\mathrm{C}-\mathrm{O}-\mathrm{C}$ groups as determined by FTIR spectroscopy to the content and valency of the abovementioned exchangeable and oxalate extractable cations and found a close positive relationship, in most cases, for soils from several field trials. The results of Ellerbrock and Gerke [66] may provide evidence for the explanation that exchangeable and oxalate extractable cations may control SOC stability in soils supporting the theory of SOC preservation by inorganic soil components. For soils which received 
farmyard manure, the SOC was more independent from the soil properties considered by Ellerbrock and Gerke [66], indicating further mechanisms of SOC preservation. However, oxalate extraction yields, to a great extent, cations complexed by organic matter, e.g., humic and fulvic acids which form humic-metal complexes [61]. Hence, the conceptual discrimination between SOC conservation either by binding SOC to inorganic soil components or intrinsic recalcitrance of SOC is an oversimplification. For example, humic substances are amphiphilic molecules $[67,68]$ with $\mathrm{O}$-or $\mathrm{N}$ - containing groups as hydrophilic component and aromatic or aliphatic regions as the lipophilic part. The reaction of phenolic or carboxylic groups of the humics with metals such as $\mathrm{Al}(\mathrm{III})$ or $\mathrm{Fe}$ (III) can lead to aggregation schemes as shown in Figure 2 for the case of $\mathrm{Al}(\mathrm{III})$.

\section{amphiphilic humic molecule}

\section{$\square \longleftarrow$ anionic/hydrophilic part (e.g. carboxylates, phenolates) lipophilic part (aromatic or aliphatic)}
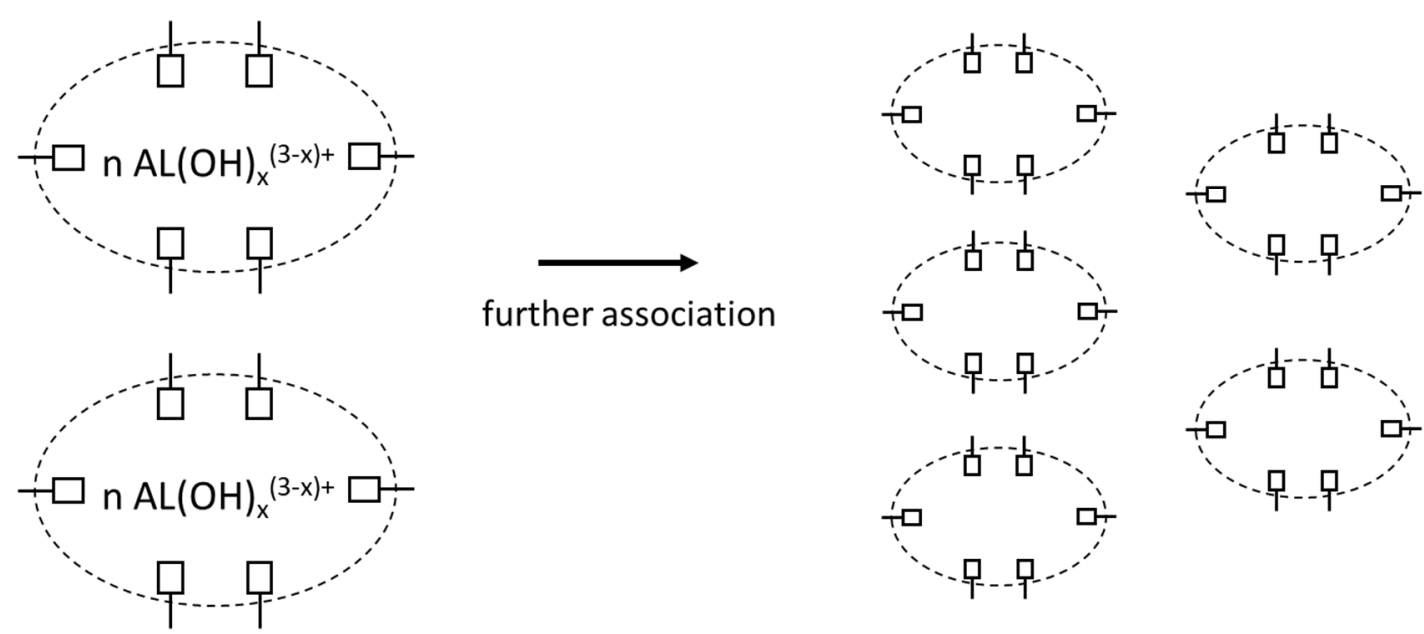

Figure 2. Schematic reactionof amphiphilic humic molecules with $\mathrm{Al}(\mathrm{III})$ : exposition of the lipophilic part and further aggregation.

The complexation of amphiphilic humic molecules by Al leads to the exposition of lipophilic parts of the humics, which allows further aggregations of higher (supramolecular) associations, decreasing water solubility, reducing the access to microorganisms, and consequently reducing microbial degradation. The reason for this assumed reduced accessibility to microbial degradation includes the complexation of $\mathrm{Al}$ which, in turn, leads to an increased recalcitrance as a consequence of the amphiphilic composition of the humic substances. The role and function of cations such as $\mathrm{Al}(\mathrm{III}), \mathrm{Fe}$ (III), or $\mathrm{Ca}$ (II) for the structure and apparent molecular weight of humic substances and its effect on the stability of soil humic substances is still a matter of debate. Engebretson and von Wandruszka [69] compared the binding of pyrene to humic substances which were pretreated in different ways. They found that humic acid with higher ash content after soft purification had a higher degree of conjugation. The acid pretreatment reduced the ash content of the humic acid which had, in turn, a higher flexibility of the polymers. Takeda et al. [60] compared the metal solubility and that of organic polymers probably dissolved humic substances in the rhizosphere soil of Brassica rapa plants and in non-rhizosphere soil by means of size exclusion chromatography. They found high concentrations of dissolved organic carbon sized between 1400 and 44,000 Da in the Brassica rapa rhizosphere soil solution compared to non-rhizosphere soil solution. Iron(III), $\mathrm{Al}(\mathrm{III})$, and to some extent $\mathrm{Cu}(\mathrm{II})$ in the rhizosphere soil solution was closely associated with the fractions of 17,000-44,000 Da. Takeda et al. [60] 
concluded, from these results, that $\mathrm{Fe}(\mathrm{III})$ and $\mathrm{Al}(\mathrm{III})$ are important for the aggregation of dissolved humic substances in the rhizosphere.

Nuzzo et al. [70] progressively increased iron complexation of both fulvic acids and humic acids. Iron complexation by fulvic acids increased their apparent molecular weight, whereas progressive iron complexation by humic acids decreased their apparent molecular weight.

Many experiments with humic substances are carried out with purified matter including acid treatment to remove mineral impurities. These impurities, however, may contain $\mathrm{Al}$ or Fe which may strongly affect structure and apparent molecular weight. The separation into fulvic and humic acids may be of limited value if the mechanisms by which humic subunits are linked are under investigation.

Soil mineral surfaces containing Fe or Mn may also affect the quantity and quality of SOC by a further mechanism. Both, $\mathrm{Fe}(\mathrm{Fe}(\mathrm{III}) / \mathrm{Fe}(\mathrm{II}))$ and $\mathrm{Mn}(\mathrm{Mn}(\mathrm{II}) / \mathrm{Mn}(\mathrm{IV})$; $\mathrm{Mn}(\mathrm{II}) / \mathrm{Mn}(\mathrm{III}))$ act as redox systems and can accelerate both the accumulation and polymerization of polyphenol monomers at the oxide or clay mineral surface [71-73] thereby catalyzing the polymerization of humic cores. Nuzzo and Piccolo [41] applied Mn catalysts and UV irradiation and reported the formation of humic macromolecules from humic supramolecular associations. This supports the view of relevance of inorganic catalysts in soil for the formation of humic substances.

The examples show that the independent consideration of SOC recalcitrance and SOC stabilization by adsorption to inorganic surfaces or by complexation is of limited value or misleading because both mechanisms interact in soil humic substances.

\section{Carbon Storage in Agricultural and Forest Soils; The Point of View of the Food and} Agricultural Organization of the United Nations (FAO)

In 2017, the FAO published a report on soil organic carbon with respect to mitigation of elevated atmospheric $\mathrm{CO}_{2}$ concentrations [74].

In this report, the authors communicate astonishing results. Humic substances do not exist according to this report, the formation of novel substances, synthesized or formed in soil, is rejected or ignored [74] (pp. 1,3). This is more than astonishing considering that about $25 \%$ of the total organic carbon on earth surface consists of humic substances [4]. Based on Schmidt et al. [7], the authors of the FAO paper state that occlusion within aggregates and binding to mineral surfaces are the principal mechanisms which regulate the persistence of soil organic carbon. Moreover, a pool of high persistence is assumed, the pool of black carbon. Experimental evidence for the BC pool is not given.

As also based on Schmidt et al. [7], the FAO report defines a specific carbon saturation of soils [74] (p. 7).

Even if the view of Schmidt et al. [7] would be majority opinion within the scientific discourse, a minority opinion of considering humic substances as an important SOC source in soils had to be included within the FAO report. However, the point of view of Schmidt et al. [7] was and is not an exclusive state of scientific knowledge. One main argument against the relevance and even existence of humic substances in soils by Schmidt et al. [7], and also Lehmann and Kleber [8], is based on alkaline extraction of soil humic substances, which may produce artifacts or is assumed to extract only biomolecules in various states of decomposition. However, humic substances are also investigated in soil solutions without harsh alkaline extractants, e.g., [59] among many others. In addition, Hayes [75] described and used a variety of different extraction solutions including mild organic solvents to extract humic substances; for a summary of these arguments, see [76]. Moreover, extraction, concentration, and purification are well-accepted procedures to gain natural organic matter from various sources [23]. In addition, model reactions of humic precursors which form molecules similar to soil humic substances have strongly contributed to the knowledge on humic substances; see, for a summary, [30]. Humic chemists are aware of the problems associated with alkaline extraction and have described procedures to avoid artifacts $[1,75,77,78]$. The argument by Schmidt et al. [7] and Lehmann and Kleber [8] that 
artifacts of alkaline extraction are a main problem in humic substance research is a special one and does not question the existence of humic substances.

Even more importantly, relevant papers have been published in the last three years, showing that humic substances are not mixtures of biomolecules. Kelleher and Simpson [79], cited by Schmidt et al. [7] and Lehmann and Kleber [8], claimed after investigating by ${ }^{1} \mathrm{H}$ NMR spectroscopy that humic substances can be explained as a mixture of plant and microbial compounds, proteins, lignin, carbohydrates, and aliphatic polymers. Cao and Schmidt-Rohr [20] reinvestigated and criticized the results of Kelleher and Simpson [79] because hydrogen nuclear magnetic resonance spectroscopy only detects carbon bound to hydrogen and focuses on small molecules. Instead, Cao and Schmidt-Rohr [20] used solid state ${ }^{13} \mathrm{CNMR}$ spectroscopy and found that humic acids strongly differ from biopolymers. Aromatic carbon not bound to hydrogen or oxygen is abundant in humic substances (mainly PAC, 28-33\%) and, also, alky C-O, abundant $\mathrm{COOH}$ groups, and aryl ketones are characteristic for humic substances but not for biopolymers [20]. These results demonstrate unique and distinct characteristics in humic substances which Kelleher and Simpson [79] did not find because of the method they applied. However, when the group of Schmidt-Rohr interpreted their NMR spectra about 6 years earlier in a different way, the abundant existence of PAC was attributed to biochar (BC) accounting for about $50 \%$ of the SOC [15]. What happened in the meantime? The group of P. Hatcher showed $[21,22,80]$ that lignin can react to polycyclic aromatic structures, e.g., by adding Fenton reagent (Fe(II) salt $+\mathrm{H}_{2} \mathrm{O}_{2}$ )which explains PAC structures in soil humic substances without participation of fire-transformed C. PAC structures in soil are a proof of the de novo synthesis of humic substances. The hypothesis of Schmidt et al. [7] and Lehmann and Kleber [8], that PAC structures have their exclusive origin in fire-derived $B C$, is wrong as shown by Chang et al. [18], Ikeya et al. [25], Waggoner et al. [80], DiDonato et al. [21], Ikeya et al. [26], and Gerke [19]. It should be noted that Ziechmann [24] (pp. 148-153) already described PAC structures in humic substances induced by the reaction of humic substances with Fenton reagent. Olk et al. [77] also argued that the formation of polyaromatic and alicyclic products in soil is in contradiction to the argument that no de novo synthesis of humic substances occurs in soil, and they showed that humic substance recovery is not dependent on alkaline extraction.

This is the actual state of the discussion which did not allow the FAO to omit humic substances from their report and did not allow the FAO to put such an uncritical viewpoint on char/BC. The role of biochar is assumed to be equal to composts and its positive effect on carbon storage in soil is emphasized. However, Gerke [19] showed that most of the statements on the positive role $\mathrm{BC} /$ biochar on soil carbon storage are unproven because the methods to determine $\mathrm{BC} /$ biochar are not specific and, in many cases, determine PAC in humic substances. Moreover, the positive effect of biochar on plant yield is stated in the FAO report. Jeffery et al. [81] showed that this is not the case. In temperate soils, crop yield is slightly depressed by the addition of biochar, and in tropical soils the yield effect of biochar is exclusively a nutrient and lime effect [81].

For the FAO report, it may be summarized that ignoring basic scientific principles does not allow the FAO to formulate substantial methods to increase soil carbon in agricultural and forest soils.

\section{Commercial Organic Fertilizers and Soil Organic Carbon}

In most cases, commercial organic fertilizers are applied to provide mineral plant nutrients within an organic framework. In this respect, these fertilizers may have advantages due to the complexing of micronutrients leaving them in a plant available fraction and the slow release of nutrients such as $P$ and $N$.

However, commercial organic fertilizers may have further effects. If they contain humic substances they may exhibit plant hormone features [82-84]. And organic fertilizers may increase the soil organic carbon content of soils. However, the direct increase of SOC by commercial organic fertilizers will be limited due to high quantities which are required. 
Farmyard manure and compost from manure may be more promising for the direct increase of SOC as a result of application.

Organic amendments may also induce the stabilization of soil organic carbon and thereby strongly increase SOC [31,45,55]. If organic applications are very effective in stabilizing and increasing SOC, commercial organic fertilizers of this type may be a future goal. Leonardite, humic acid extracted from coal, may be the basis for them.

Erro et al. [85] suggested a chemical structure of Leonardite humic acid which they incorporated into NPK fertilizers. Urrutia et al. [86] described new P fertilizers of the humic-metal-P type which may deliver more sustainable P fertilizers and which may have also a function in stabilizing soil organic carbon.

Funding: This research received no external funding.

Conflicts of Interest: The author declares no conflict of interests.

\section{References}

1. Stevenson, F.J. Humus Chemistry: Genesis, Composition, Reactions; John Wiley: New York, NY, USA, 1994.

2. Ghabbour, E.A.; Davies, G.; Daggett, J.L., Jr.; Worgul, C.H.A.; Wyant, G.A.; Sayedbagheri, M.M. Measuring the humic acid content of commercial lignites and agricultural top soils in the national soil project. Ann. Environ. Sci. 2012, 6, 1-12.

3. Batjes, N.H. harmonized soil property values for broad-scale modeling with estimates of global soil carbon stocks. Geoderma 2016, 269, 61-68. [CrossRef]

4. Weber, J.; Chen, Y.; Janroz, E.; Miano, T. Preface: Humic substances in the environment. J. Soils Sediments 2018, 18, 2665-2667. [CrossRef]

5. Gattinger, A.; Muller, A.; Haeni, M.; Skinner, C.; Fliessbach, A.; Buchmann, N. Enhanced top soil carbon stocks under organic farming. Proc. Natl. Acad. Sci. USA 2012, 109, 18226-18231. [CrossRef] [PubMed]

6. Forstreuter, T. Bodenfruchtbarkeitskennwerte und Kulturpflanzenertrag in zwei Bodennutzungssystemen. Ph.D. Thesis, GeorgAugust-Universität Göttingen, Göttingen, Germany, 1999.

7. Schmidt, M.W.I.; Torn, M.S.; Abiven, S.; Dittmar, T.; Guggenberger, G.; Janssens, I.A.; Kleber, M.; Kögel-Knabner, I.; Lehmann, J.; Manning, D.A.C.; et al. Persistence of soil organic matter as an ecosystem property. Nature 2011, 478, 49-56. [CrossRef] [PubMed]

8. Lehmann, J.; Kleber, M. The contentious nature of soil organic matter. Nature 2015, 528, 61-68. [CrossRef] [PubMed]

9. Marschner, B.; Brodowski, S.; Dreves, A.; Gleixner, G.; Gude, A.; Grootes, P.M.; Hamer, U.; Heim, A.; Jandl, G.; Ji, R.; et al. How relevant is recalcitrance for the stabilization of organic matter in soils? J. Plant Nutr. Soil Sci. 2008, 171, 91-110. [CrossRef]

10. Schmidt, M.W.I.; Skjemstad, J.O.; Gehrt, E.; Kögl-Knabener, I. Charred organic carbon in German chernozemic soils. Eur. J. Soil Sci. 1999, 50, 351-365. [CrossRef]

11. Schmidt, M.W.I.; Skjemstad, J.O.; Jäger, C. Carbon isotope geochemistry and nano morphology of soil black carbon: Black chernozemic soils in central Europe originate from ancient biomass burning. Glob. Biogeochem. Cycles 2002, 16, $1123-1131$. [CrossRef]

12. Skjemstad, J.O.; Taylor, J.A.; Smernik, R.J. Estimation of charcoal (char) in soils. Commun. Soil Sci. Plant Anal. 1999, 30, 2283-2298. [CrossRef]

13. Glaser, B.; Haumeier, G.; Guggenberger, G.; Zech, W. The terra pretaphenomen: A model for sustainable agriculture in the humid tropics. Naturwissenschaften 2001, 88, 37-41. [CrossRef]

14. Skjemstad, J.O.; Reikosky, D.C.; Wilts, A.R.; McGowan, J.A. Charcoal carbon in US agricultural soils. Soil Sci. Soc. Am. J. 2002, 66, 1249-1255. [CrossRef]

15. Mao, J.-D.; Johnson, R.L.; Lehmann, J.; Olk, D.C.; Neves, E.G.; Thompson, M.L.; Schmidt-Rohr, K. Abundant and stable char residues in soils: Implications for soil fertility and carbon sequestration. Environ. Sci. Technol. 2012, 46, 9571-9576. [CrossRef]

16. Schmidt, M.W.I.; Skjemstad, J.O.; Czimczik, C.I.; Glaser, B.; Prentice, K.M.; Gelinas, Y.; Kühlbusch, T.A. Comparative analysis of black carbon in soils. Glob. Biogeochem. Cycles 2001, 15, 163-167. [CrossRef]

17. Zimmermann, A.R.; Mitra, S. Trial by fire: On the terminology and methods used in pyrogenic organic carbon research. Front. Earth Sci. 2017, 5, 95. [CrossRef]

18. Chang, Z.; Tian, L.; Li, F.; Zhou, Y.; Wu, M.; Steinberg, C.; Dong, X.; Pan, B.; Xing, B. Benzene carboxylic acid-A useful marker for condensed organic matter, but not only for pyrogenic black carbon. Sci. Total Environ. 2018, 626, 660-667. [CrossRef] [PubMed]

19. Gerke, J. Black (pyrogenic) carbon in soils and waters: A fragile data basis extensively interpreted. Chem. Biol. Technol. Agric. 2019, 6, 13. [CrossRef]

20. Cao, X.; Schmidt-Rohr, K. Abundant non protonated aromatic and oxygen- bonded carbons make humic substances distinct from biopolymers. Environ. Sci. Technol. Lett. 2018, 5, 475-480. [CrossRef]

21. DiDonato, N.; Chen, H.; Waggoner, D.; Hatcher, P. Potential origin and formation for molecular components of humic acids in soils. Geochim. Cosmochim. Acta 2016, 178, 201-222. [CrossRef]

22. Waggoner, D.C.; Hatcher, P.G. Hydroxyl radical alteration of HPLC fractionated lignin: Formation of new compounds from terrestrial organic matter. Org. Geochem. 2017, 113, 315-325. [CrossRef] 
23. Piccolo, A. In memoriam Prof. F.J. Stevenson and the question of humic substances in soil. Chem. Biol. Technol. Agric. $2016,3,23$. [CrossRef]

24. Ziechmann, W. Huminstoffe; Verlag Chemie: Weinheim, Germany, 1980.

25. Ikeya, K.; Sleighter, R.L.; Hatcher, P.G.; Watanabe, A. Characterization of the chemical composition of soil humic acids using Fourier transform ion cyclotron resonance spectroscopy. Geochim. Cosmochim. Acta 2015, 153, 169-182. [CrossRef]

26. Ikeya, K.; Maie, N.; Han, X.; Wang, G.; Watanabe, A. Comparison of skeletal structures in black humic acids from different soil origins. Soil Sci. Plant Nutr. 2019, 65, 109-113. [CrossRef]

27. Brodowski, S.; Rodionow, A.; Haumeier, L.; Glaser, B.; Amelung, W. Revised black carbon assessment using benzene polycarboxylic acids. Org. Geochem. 2005, 35, 1299-1310. [CrossRef]

28. Boudot, J.P. Relative efficiency of complexed aluminum, noncrystalline Al hydroxide, allophane and imogolite in retarding the biodegradation of citric acid. Geoderma 1992, 52, 29-39. [CrossRef]

29. Jones, D.L.; Edwards, A.C. Influence of sorption on the biological utilization of two simple carbon substrates. Soil Biol. Biochem. 1998, 30, 1895-1902. [CrossRef]

30. Gerke, J. Concepts and misconceptions of humic substances as the stable part of soil organic matter: A review. Agronomy 2018, 8 , 76. [CrossRef]

31. Piccolo, A.; Spaccini, R.; Drosos, M.; Vinci, M.; Cozzolini, V. The molecular composition of humus carbon: Recalcitrance and reactivity in soils. In The Future of Soil Carbon; Garcia, C., Nannipieri, P., Hernandez, T., Eds.; Academic Press: London, UK, 2018; pp. 87-124.

32. Haider, K. Biochemie des Bodens; Enke: Stuttgart, Germany, 1995.

33. Tunega, D.; Gerzabek, M.H.; Haberhauer, G.; Lischka, H.; Sole, R.; Aquino, A.J.A. Adsorption process of polar and nonpolar compounds in a nanopore model of humic substances. Eur. J. Soil Sci. 2020, 71, 845-855. [CrossRef]

34. Swift, R.S. Macromolecular properties of soil humic substances: Fact, fiction and opinion. Soil Sci. 1999, 164, 790-802. [CrossRef]

35. Piccolo, A. The supramolecular structure of humic substances. Soil Sci. 2001, 166, 810-832. [CrossRef]

36. Piccolo, A. The supramolecular structure of humic substances: A novel understanding of humus chemistry and implications in soil science. Adv. Agron. 2002, 75, 57-134.

37. Piccolo, A.; Conte, P. Molecular size of humic substances. Supramolecular associations versus macromolecular polymers. Adv. Environ. Res. 2000, 3, 508-521.

38. Fuentes, M.; Baigorri, R.; Garcia-Mina, J.M. Maturation in composting process, an incipient humification-like step an multivariate statistical analysis of spectroscopic data shows. Environ. Res. 2020, 189, 109981. [CrossRef] [PubMed]

39. Piccolo, A.; Cozzolino, A.; Conte, P.; Spaccini, R. Polymerization of humic substances by an enzyme catalyzed oxidative coupling. Naturwissenschaften 2000, 87, 391-394. [CrossRef] [PubMed]

40. Cozzolino, A.; Piccolo, A. Polymerization of dissolved humic substances catalyzed by peroxidase. Effects of pH and humic composition. Org. Geochem. 2002, 33, 281-294. [CrossRef]

41. Nuzzo, A.; Piccolo, A. Oxidative and photo-oxidative polymerization of humic superstructures by heterogeneous biomimetic catalysis. Biomacromolecules 2013, 14, 1645-1652. [CrossRef]

42. Verma, L.; Martin, J.P.; Haider, K. Decomposition of ${ }^{14} \mathrm{C}$ - labeled proteins, peptides and aminoacids: Free and complexed with humic polymers. Proc. Soil Sci. Soc. Am. 1975, 39, 279-284. [CrossRef]

43. Martin, J.P.; Zunino, H.; Peirano, P.; Caiozzi, M.; Haider, K. Decomposition of 14C- labeled lignins, model humic acid polymers and fungal melanins in allophanic soils. Soil Biol. Biochem. 1982, 14, 289-293. [CrossRef]

44. Martin, J.P.; Haider, K. Influence of mineral colloids on turnover rates of soil organic carbon. In Interactions of Soil Minerals with Natural Organics and Microbes; Huang, P.M., Schnitzer, M., Eds.; Soil Science Society America: Madison, WI, USA, 1986; pp. 283-304.

45. Piccolo, A.; Spaccini, R.; Nieder, R.; Richter, J. Sequestration of biologically labile organic carbon in soils by humified organic matter. Clim. Chang. 2004, 67, 329-343. [CrossRef]

46. Körschens, M.; Albert, E.; Baumecker, M.; Ellmer, F.; Grunert, M.; Hoffmann, S.; Kismányoky, T.; Kubát, J.; Kunzová, E.; Marx, M.; et al. Humus und Klimaänderung- Ergebnisse aus 15 langjährigen Dauerfeldversuchen. Arch. Agron. Soil Sci. 2014, 60, 1485-1517. [CrossRef]

47. Inbar, Y.; Chen, Y.; Hadar, Y. Humic substances formed during composting of organic matter. Soil Sci. Soc. Am. J. 1990, 54, 1316-1323. [CrossRef]

48. Chen, Y.; Inbar, Y. Chemical and spectroscopic analyses of organic matter transformation during composting in relation to compost maturity. In Science and Engineering of Composting: Design, Environmental, Microbial and Utilization Aspects; Hoitink, H.A.J., Keener, H.M., Eds.; Ohio State University: Wooster, OH, USA, 1993; pp. 551-600.

49. Chen, Y.; Chefetz, B.; Hadar, Y. Formation and properties of humic substances originating from composts. In The Science of Composting; De Bertoldi, M., Sequi, P., Leumes, B., Papi., T., Eds.; Springer: Dorderecht, NL, USA, 1996; pp. $382-393$.

50. Baddi, G.A.; Hafidi, M.; Gilard, V.; Revel, J.C. Characterization of humic acids produced during composting olive mill wastes: Elemental and spectroscopic analyses (FTIR and $\left.{ }^{13} \mathrm{C}-\mathrm{NMR}\right)$. Agronomie 2003, 23, 661-666. [CrossRef]

51. Huang, G.F.; Wu, Q.T.; Wong, J.W.C.; Naggar, B.B. Transformation of organic matter during co- composting of pig manure with sawdust. Biores. Technol. 2006, 97, 1834-1842. [CrossRef] 
52. Adani, F.; Genevini, P.L.; Tambone, F.; Montoneri, E. Compost effect on soil humic acid. A NMR study. Chemosphere 2006, 65, 1414-1418. [CrossRef] [PubMed]

53. Adani, F.; Spagnol, M. Humic acid formation in artificial soils amended with compost at different stages of organic matter evolution. J. Environ. Qual. 2008, 37, 1608-1616. [CrossRef]

54. Smidt, E.; Meissl, K.; Schmutzer, M.; Hinterstoisser, B. Co-composting of lignin to build up humic substances- strategies in waste management to improve compost quality. Industr. Crop. Product. 2008, 27, 196-201. [CrossRef]

55. Spaccini, R.; Piccolo, A. Soil organic carbon stabilization in compost amended soils. In Global Symposium on Soil Organic Carbon; FAO: Rome, Italy, 2017.

56. Weichelt, T. Chemical alteration of natural lignin by interactions with humic like autoxidation products of pyrogallol (1,2,3 trihydroxybenzene). In Soil Organic Matter Studies; IAEA: Wien, Austria, 1977; pp. 67-82.

57. Albuzio, A.; Ferrari, G. Modulation of molecular size of humic substances by organic acids of the root exudates. Plant Soil 1989, 113, 237-241. [CrossRef]

58. Gerke, J. Solubilization of Fe(III) from humic-Fe complexes, humic-Fe-oxide mixtures and from poorly ordered Fe-oxide by organic acids- consequences for P adsorption. J. Plant Nutr. Soil Sci. 1993, 156, 253-257. [CrossRef]

59. Gerke, J.; Meyer, U. Phosphate acquisition by red clover and black mustard on a humic podzol. J. Plant Nutr. 1995, 18, $2409-2429$. [CrossRef]

60. Takeda, A.; Tsukada, H.; Takaku, Y.; Hisamatsu, S. Fractionation of metal complexes with dissolved organic matter in a rhizosphere soil solution of a humus- rich Andosol using size exclusion chromatography with inductively coupled plasma-mass spectrometry. Soil Sci. Plant Nutr. 2009, 55, 349-357. [CrossRef]

61. Gerke, J. Humic (organic matter)-Al(Fe)-phosphate complexes: An underestimated phosphate form in soils and source of plant-available phosphate. Soil Sci. 2010, 175, 417-425. [CrossRef]

62. Nuzzo, A.; De Martino, A.; Di Meo, V.; Piccolo, A. Potential alteration of iron-humate complexes by plant root exudates and microbial siderophores. Chem. Biol. Technol. Agric. 2018, 5, 19. [CrossRef]

63. Kleber, M.; Eusterhues, K.; Keiluweit, M.; Mikutta, C.; Mikutta, R.; Nico, P.S. Mineral-organic associations. Formation, properties and relevance in soil environments. Adv. Agron. 2015, 130, 1-140.

64. Gu, B.H.; Schmidt, J.; Chen, Z.; Liang, L.; McCarthy, J.F. Adsorption and desorption of natural organic matter on iron oxide: Mechanisms and models. Environ. Sci. Technol. 1994, 28, 38-46. [CrossRef] [PubMed]

65. Schwesig, D.; Kalbitz, K.; Matzner, E. Effects of aluminum on the mineralization of dissolved organic carbon derived from forest floors. Eur. J. Soil Sci. 2003, 54, 311-322. [CrossRef]

66. Ellerbrock, R.H.; Gerke, H.H. Explaining soil organic matter composition based on associations between OM and polyvalent cations. J. Plant Nutr. Soil Sci. 2018, 181, 721-736. [CrossRef]

67. Von Wandruszka, R. The micellar model of humic acid: Evidence from pyrene fluorescence measurements. Soil Sci. 1998, 163, 921-930. [CrossRef]

68. Wershaw, R.L. Molecular aggregation of humic substances. Soil Sci. 1999, 164, 803-813. [CrossRef]

69. Engebretson, R.R.; Von Wandruszka, R. Effect of humic acid purification on interactions with hydrophobic organic matter: Evidence from fluorescence behavior. Environ. Sci. Technol. 1999, 33, 4299-4303. [CrossRef]

70. Nuzzo, A.; Sanchez, A.; Fontaine, B.; Piccolo, A. Conformational changes of dissolved humic and fulvic superstructures with progressive iron complexation. J. Geochem. Explor. 2013, 129, 1-5. [CrossRef]

71. Wang, T.S.C.; Li, S.W.; Huang, P.N. catalytic polymerization of phenolic compounds by a latosol. Soil Sci. 1978, 126, 81-86. [CrossRef]

72. Wang, T.S.C.; Wang, M.C.; Yue, L.; Huang, P.M. Catalytic synthesis of humic substances by natural clays, silts and soils. Soil Sci. 1983, 135, 350-360. [CrossRef]

73. Shindo, H. Catalytic synthesis of humic acids from phenolic compounds by Mn(IV) (Birnessite). Soil Sci. Plant Nutr. 1990, 36, 679-682. [CrossRef]

74. FAO. Soil Organic Carbon, the Hidden Potential; FAO: Rome, Italy, 2017.

75. Hayes, M.H.B. Solvent systems for the isolation of organic components from soils. Soil Sci. Soc. Am. J. 2006, 70, 984-994. [CrossRef]

76. Zanin, L.; Tomasi, N.; Cesco, S.; Varanini, Z.; Pinton, R. Humic substances contribute to plant iron nutrition acting as chelators and biostimulants. Front. Plant Sci. 2019, 10, 675. [CrossRef]

77. Olk, D.C.; Bloom, P.R.; Perdue, E.M.; McKnight, D.M.; Chen, Y.; Farenhorst, A.; Senesi, N.; Chin, Y.-P.; Schmitt-Kopplin, P.; Hertkorn, N.; et al. Environmental and agricultural relevance of humic fractions extracted by alkali from soils and natural waters. J. Environ. Qual. 2019, 48, 217-232. [CrossRef] [PubMed]

78. Hayes, M.H.B.; Swift, R.S. Vindication of humic substances as a key component of organic matter in soil and water. Adv. Agron. 2020, 163, 1-37.

79. Kelleher, B.P.; Simpson, A.J. Humic substances in soils: Are they really chemically distinct? Environ. Sci. Technol. 2006, 40, 4605-4611. [CrossRef] [PubMed]

80. Waggoner, D.C.; Chen, H.; Willoughby, A.S.; Hatcher, P.G. Formation of black carbon- like and alicyclic aliphatic compounds by hydroxyl radical initiated degradation of lignin. Org. Geochem. 2015, 82, 69-76. [CrossRef] 
81. Jeffery, S.; Abalos, D.; Prodana, M.; Bastos, A.C.; Van Groenigen, J.W.; Hungate, B.A.; Verheijen, F. Biochar boosts tropical but not temperate crop yield. Environ. Res. Lett. 2017, 12, 053001. [CrossRef]

82. Canellas, L.P.; Olivares, F.L. Physiological responses to humic substances as plant growth promoter. Chem. Biol. Technol. Agric. 2014, 1, 1-11. [CrossRef]

83. Nardi, S.; Ertani, A.; Francioso, O. Soil-root cross- talking: The role of humic substances. J. Plant Nutr. Soil Sci. 2017, 180, 5-13. [CrossRef]

84. Urrutia, O.; Erro, J.; Fuentes, M.; Olaetxea, M.; Garnica, M.; Baigorri, R.; Zamarreno, A.M.; Movila, M.; DeHita, D.; Garcia-Mina J.M. The effect of soil organic matter on plant mineral nutrition. In Achieving Sustainable Crop Nutrition; Rengel, Z., Ed.; Burleigh Dodds: Cambridge, UK, 2020; pp. 1-11.

85. Erro, J.; Urrutia, O.; Baigorri, R.; Fuentes, M.; Zamerreno, G.; Garcia-Mina, J.M. Incorporation of humic- derived active molecules into compound NPK granulated fertilizers. Chem. Biol. Technol. Agric. 2016, 3, 18-33. [CrossRef]

86. Urrutia, O.; Erro, J.; Guardado, L.; San Francisco, S.; Mandado, M.; Baigorri, R.; Claude Yvin, J.; Garcia-Mina, J.M. Physicochemical characterization of humic-metal- phosphate complexes and their potential application to the manufacture of new types of phosphate- based fertilizers. J. Plant Nutr. Soil Sci. 2014, 177, 128-136. [CrossRef] 